\title{
Stock delineation in Clupisoma garua (Hamilton, 1822) populations of Ganga riverine system using truss network analysis
}

\author{
IPSITA BISWAS, T. S. NAGESH AND A. M. SAJINA* \\ Department of Fisheries Resource Management, Faculty of Fishery Sciences, West Bengal Univeristy \\ of Animal and Fishery Sciences, Kolkata - 700 094, West Bengal, India \\ *Fisheries Resource and Environment Management Division, ICAR-Central Inland Fisheries Research Institute \\ Barrackpore, Kolkata - 700 120, India \\ e-mail: ipsitabiswas24@gmail.com
}

\section{ABSTRACT}

\begin{abstract}
Stock identification of fish plays a significant role in management of fishery resources. It is considered as the precursor to the species conservation and imperative for declining fish populations. The stock structure of Clupisoma garua (Hamilton, 1822) populations of Ganga riverine system was studied using truss network analysis. A total of 306 fish specimens obtained from river Ganga in Allahabad, Farakka and Triveni were used to construct the truss network. The truss variables were subjected to principal component analysis (PCA) in which the first component explained $46.71 \%$ and the second $14.66 \%$ representing body depth and caudal regions of fish, respectively. Bivariate plots of PCA and discriminant function (DF) analysis revealed that it is a single continuous stock in the study area of the river Ganga and the misclassification of DF indicated only a marginal morphological difference. The results indicated the need for a uniform management strategy appropriate for population of $C$. garua in the river Ganga.
\end{abstract}

Keywords: Catfish, Conservation, Ganga River, PCA, Stock assessment

\section{Introduction}

Presently, the concept of fish stock identification is getting popular in terms of sustainability. Stocks are defined as a self-sustaining population which comes from the same gene pool, more or less isolated from the same species. Inadequate knowledge on population differentiation and connectivity may impact the accuracy of stock assessment, whereby management decision could result in recruitment failures, loss of productivity and reduced yields (Cadrin and Friedland, 2005).

One of the most frequently used and cost effective method for identification of stock is analysing morphometric variation in fish. Morphometric variables are measured from the distance based on anatomical landmarks to study the phylogeny, phenotypic plasticity and fish condition. The conventional morphometric analysis mostly relied on the measurement along the longest axis of the body, thus making it difficult to measure the actual aspect of body shape (Bookstein et al., 1985). In contrast, truss network method is not dominated by excessive measurement along single axis which presents a comprehensive characterisation of shape and thus it is considered as a powerful tool to describe morphological differentiation (oblique, horizontal and vertical) for individual classification and intraspecific identification (Strauss and Bookstein, 1982; Turan, 1999).

The species Clupisoma garua (Hamilton, 1822) along the Ganga River commonly known as Garua bachcha or river catfish belongs to family Schilbeidae. It is a subtropical freshwater catfish inhabiting the bottom niche in riverine ecosystem of Gangetic plains having high percentage of fat content (Jafri et al., 1964; Talwar and Jhingran, 1991). C. garua commonly feeds on molluscs, insects, crustaceans, decaying matter and sometimes algal matters (Hora, 1929). The species was considered as a Least Concern species under IUCN Red List of Threatened Species (IUCN, 2017) but it was reported as Vulnerable in River Betwa (Lakra et al., 2010; Dubey et al., 2013). Moreover, C. garua is recognised as vulnerable species (CAMP, 1998; CAFF, 2006) and a gradual reduction in natural population has been observed (Saraswat et al., 2013). The catch rate of C. garua has declined by about $30.4 \%$ during 1960-2000 in Sundarbans and $27.7 \%$ in south-western Bengal (Patra et al., 2005; Mishra et al., 2009). Insufficient information regarding its distribution was noticed in other localities (Verma et al., 2014; Siddik et al., 2017; Biswas et al., 2018).

To determine stock structure of a single species several complimentary techniques need to be assesed 
The findings of Biswas et al. (2018) using conventional morphometric variations and meristic counts revealed multiple stocks of C. garua in the middle and lower Gangetic regions. Therefore, to facilitate stock assessment, it was felt essential to comprehend the stock structure of C. garua along the Ganga River using truss network by considering complete body archive without any information loss. Though several fish faunal studies were conducted in River Ganga and its tributaries (Hamilton, 1822; Hora, 1929; Sarkar et al., 2012) sufficient data on Schilbid freshwater catfish was lacking. Hence, the aim of the present study was to assess the stock structure of C. garua in the middle and lower stretches of the Ganga River by emphasising on truss network.

\section{Materials and methods}

\section{Collection of samples}

A total of 306 specimens of C. garua were obtained from three locations of the river Ganga, viz., Allahabad $(n=100)$, Farakka $(n=109)$ and Triveni $(n=97)$ in India during March and May, 2016 (Fig. 1). The sampling was done prior to breeding season (June-August) of the species for putative stock identification (Hora, 1938; Chondar, 1999). The specimens were collected from commercial fish catch in gillnet and hook and line, followed by screening for any physical damages. Simple random sampling was adopted to collect the fish from the landing centre. The collected specimens were preserved in ice in an insulated box and transported to the laboratory for further analysis.

\section{Digitisation of samples}

Digital images of the samples were taken after thawing the samples in running tap water. After thawing, the samples were wiped well and placed on a platform with horizontal and vertical grids forming square of $1 \mathrm{~cm}^{2}$ size to calibrate the coordinates of the digital images. The body and fins of the samples were stretched to natural position for facilitating the visibility of insertion points. Homologous anatomical landmarks across specimens were marked by piercing round head pins to get an effective discrimination among the group (Winans, 1987). Digital camera mounted on a leveling tripod was utilised to capture the images (Nikon Coolpix L840 16.0 MP). For perfect alignment, bubble level was monitored to provide a complete structural archive of the sample (Cadrin and Friedland, 1999).

\section{Measurement of truss distance}

To convert the images from JPEG (*.jpeg) to TPS (*.tps), tpsUtil V1.38 (Rohlf, 2006a) program was used. The truss distances were extracted from the digitised image using tpsDig2 V2.1 (Rohlf, 2006b) and Paleontological STatistics (PAST) (Hammer et al., 2001) to construct an inter linked network of thirteen landmarks to form 27 truss measurements (Fig. 2).

\section{Analysis of truss morphometric data}

All data of truss measurement were transformed and its normality tested by SAS PROC UNIVARIATE procedure (SAS, 2008). An allometric approach was employed for size correction (Ihssen et al., 1981; Hurlbut and Clay, 1998).

$$
\mathrm{M}_{\text {trans }}=\left(\mathrm{SL}_{\text {mean }} / \mathrm{SL}\right)^{\mathrm{b}}
$$

where, $\mathrm{M}_{\text {trans }}=$ Transformed truss measurement, $\mathrm{M}=$ Original truss measurement, $\mathrm{SL}=$ Standard length of fish, $\mathrm{SL}_{\text {mean }}=$ Overall mean standard length and $\mathrm{b}=$ Within-group slope regressions of the $\log \mathrm{M}$ against $\operatorname{logSL}$.

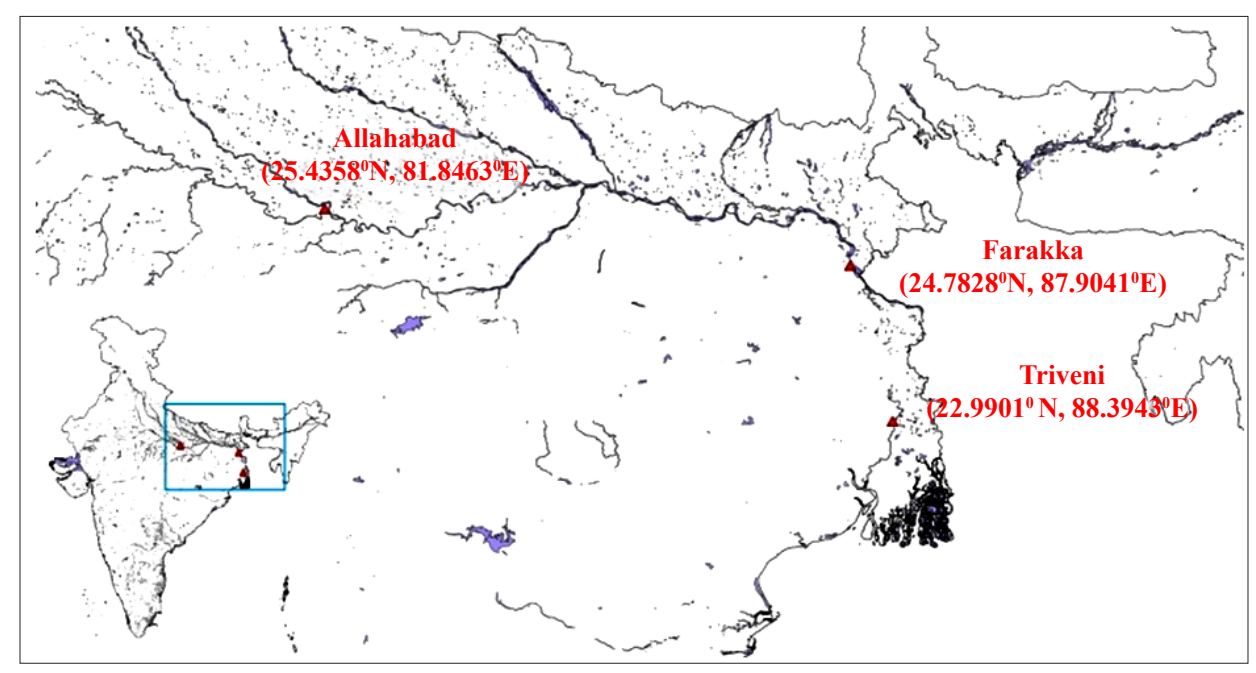

Fig 1. Sampling locations of C. garua along the river Ganga 


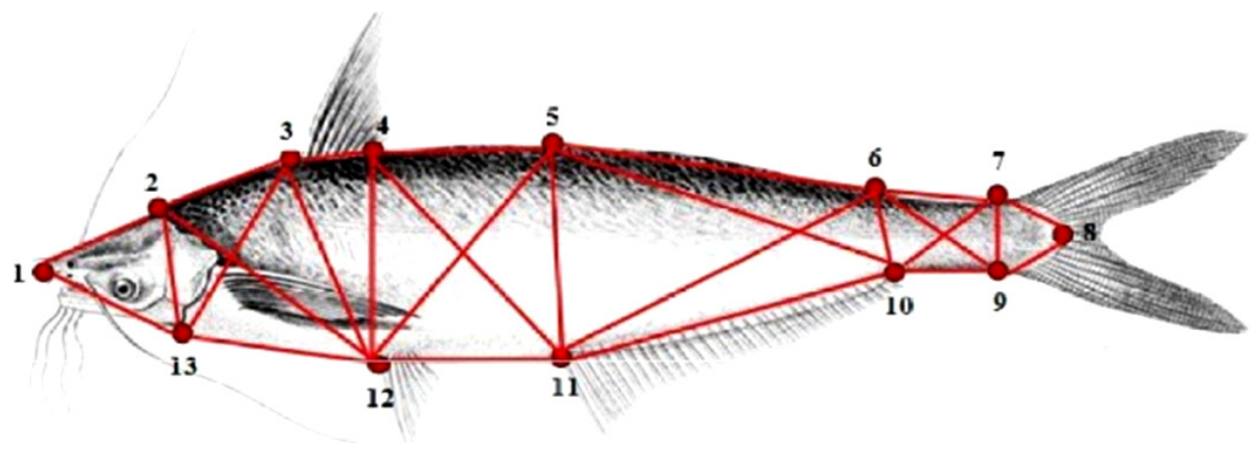

Fig. 2. Truss network of C. garua

Correlation coefficient was calculated between the transformed data and SL of the fish to test whether data transformation is effective in removing the effect of size. Twenty seven size corrected truss measurements were exposed to principal component analysis (PCA) by PROC FACTOR procedure in SAS (SAS, 2008). Classification of individuals through cross-validation of the discriminant analysis was then exerted using PROC DISCRIM procedure of SAS (SAS, 2008).

\section{Results}

None of the standard truss measurements showed correlation with SL, which indicated that the body length effect has been removed by allometric transformation of data. The component loadings of the 27 truss distances (variables) are listed in Table 1 and it shows the variance explained by the variable on that particular component. The variables highlighted (with asterisk) are the variables with meaningful loading.

First two components of the PCA in the present study accounted for $61.37 \%$ of total morphometric variation. The characters belonging to depth of body and belly region were loaded highly on $\mathrm{PC} 1$ and the caudal portions were loaded on PC2 which accounted for $46.71 \%$ and $14.66 \%$ of total variance respectively. Variables loaded on first factor were all positive, indicating a positive correlation between variables within $\mathrm{PC} 1$. The truss distances with meaningful loading on PC1 were 2-12, 3-12, 4-11, 5-11, 5-12 and 12-13 (Fig. 3a) and were found to be significant. All these six distances characterised the anterior half of the fish body with depth measurements and horizontal abdominal position. PC2 explained $14.66 \%$ of total variation with two significant loadings which were 6-7 and 6-9 truss distances (Fig. 3b). In PC2, both positive and negative correlations were observed on trait loading.

The populations of Allahabad, Farakka and Triveni (Fig. 4) showed a single cluster due to marginal separation. Cross-validation of the discriminant analysis correctly classified $82.00,88.07$ and $85.57 \%$ of individuals of
Table 1. Variable loadings in principal component analysis of truss distance

\begin{tabular}{|c|c|c|}
\hline Truss distances $(\mathrm{cm})$ & $\mathrm{PC} 1$ & $\mathrm{PC} 2$ \\
\hline 01-02 & 0.1084 & -0.1488 \\
\hline $01-13$ & 0.0701 & -0.1272 \\
\hline $02-03$ & 0.1034 & 0.0480 \\
\hline $02-12$ & $0.2749 *$ & 0.1412 \\
\hline $02-13$ & 0.1067 & -0.0638 \\
\hline 03-04 & 0.0510 & -0.0540 \\
\hline $03-12$ & $0.2934 *$ & 0.1754 \\
\hline $03-13$ & 0.1934 & -0.0276 \\
\hline 04-05 & 0.1365 & 0.1219 \\
\hline $04-11$ & $0.3068 *$ & 0.1599 \\
\hline $04-12$ & 0.2965 & 0.2030 \\
\hline $05-06$ & 0.2034 & -0.4776 \\
\hline $05-10$ & 0.2837 & -0.3459 \\
\hline $05-11$ & $0.2766^{*}$ & 0.1093 \\
\hline $05-12$ & $0.2795^{*}$ & 0.1602 \\
\hline $06-07$ & 0.1159 & $0.2826^{*}$ \\
\hline 06-09 & 0.1426 & $0.2119^{*}$ \\
\hline $06-10$ & 0.1325 & 0.0721 \\
\hline $06-11$ & 0.2784 & -0.3272 \\
\hline 07-08 & 0.0560 & -0.0479 \\
\hline 07-09 & 0.1038 & 0.0056 \\
\hline $07-10$ & 0.1413 & 0.1693 \\
\hline 08-09 & 0.0874 & -0.0155 \\
\hline $09-10$ & 0.0598 & 0.1685 \\
\hline $10-11$ & 0.2313 & -0.3665 \\
\hline $11-12$ & 0.1173 & 0.0240 \\
\hline $12-13$ & $0.2021 *$ & 0.0446 \\
\hline
\end{tabular}

Allahabad, Farakka and Triveni populations, respectively. In this study, 85.21\% individuals were well classified (Table 2).

\section{Discussion}

Stock identification and its quantification is essential to assess fishing pattern and state of the fishery resources (Gulland, 1971; Hilborn and Walters, 1992) to obtain the optimum yield over a long period of time. Generally, fishes show a high degree of variation within and among 


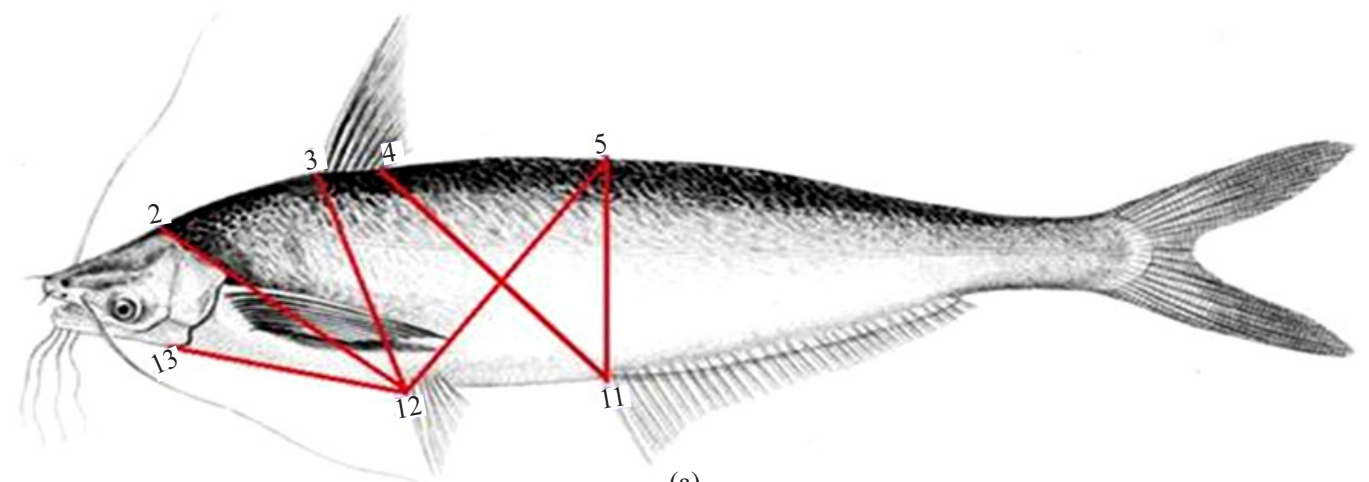

(a)

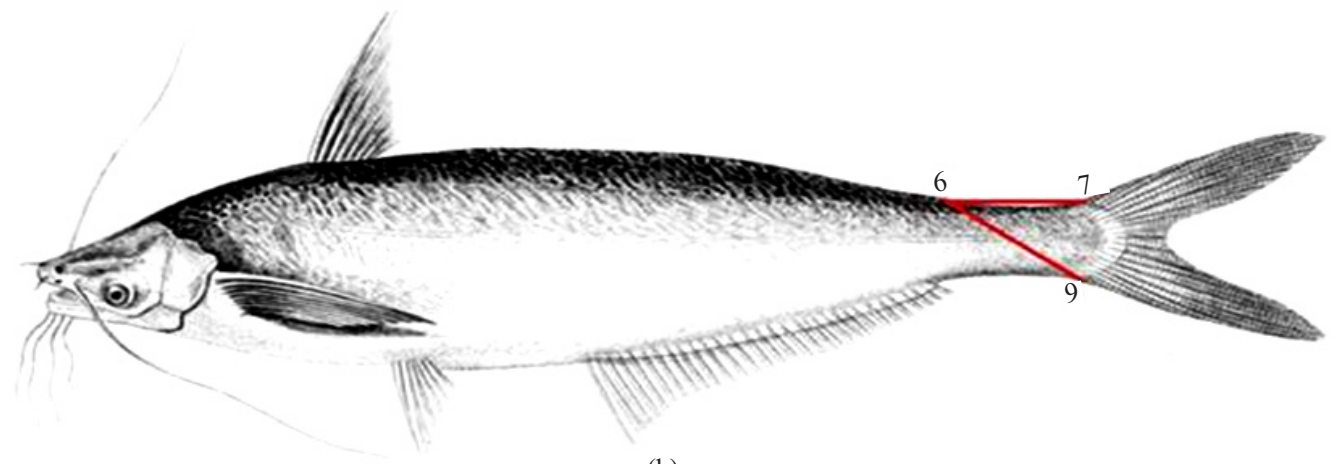

(b)

Fig. 3. Distances with meaningful loadings on (a) PC1 and (b) PC2 components in truss network analysis of C. garua

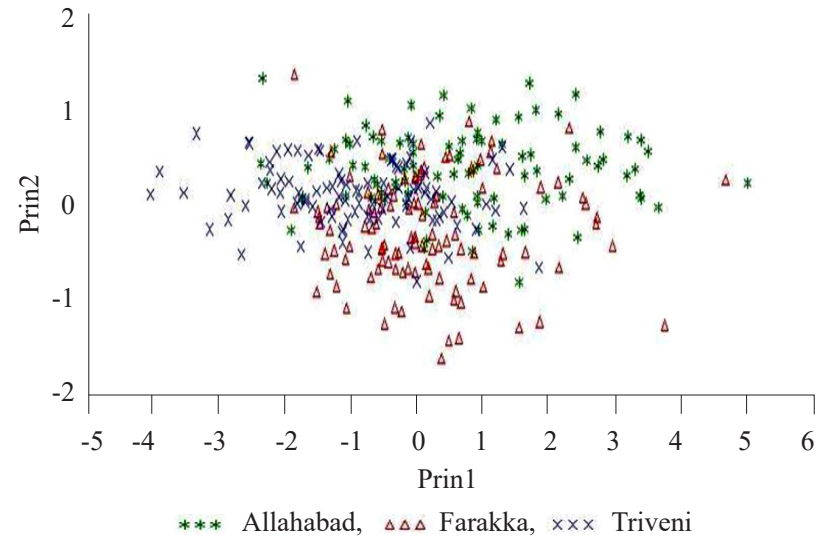

Fig 4. Bivariate plot of scores on the two components extracted from 13 point truss measurements of C. garua

populations than other vertebrates and furthermore, the local habitats influence the morphological variations due to multiple stock reproduction and migration, which assists in distinguishing fish populations (Wimberger, 1992). Improper knowledge of such variations results in stock structure obscurity and genetic diversity loss, thus highlighting the importance of stock identification and its delineation.
Table 2. Percentage of fish from each location (in rows) classified in each location (in columns) in the cross validation of the discriminant analysis

\begin{tabular}{llll}
\hline Location & Allahabad & Farakka & Triveni \\
\hline Allahabad & 82.00 & 8.00 & 10.00 \\
Farakka & 6.42 & 88.07 & 5.50 \\
Triveni & 2.06 & 12.37 & 85.57 \\
Total rate of classification (\%) & & 85.21 & \\
Total rate of misclassification & & 14.79 & \\
$(\%)$ & & & \\
\hline
\end{tabular}

The present study on truss-based morphometrics exposed the phenotypic homogeneity among the populations of $C$. garua in three localities of Ganga River which may be due to inevitable migratory behaviour of the species, and as a result reproductive isolation was not noticed (Kumar et al., 2012). PCA is a data reduction technique which facilitates identification of variables with high loading for a given component which is then subjected to scratching procedure as described by Hatcher (2003). Eigen values obtained from the covariance matrix using PCA, explained variations of about $46.71 \%$ from first component and $14.66 \%$ from the second representing body depth and caudal regions of fish, respectively caused 
by different components. All the six distances that showed meaningful loadings on PC1 were positively correlated with major vertical size dimensions on the anterior side of fish body which has also been reported in Serranids (Cavalcanti et al., 1999) and in Megalaspis cordyla (Sajina et al., 2011). On the other hand, traits loaded on PC2 belonged to caudal region represented with positive and negative correlation. Variation in caudal region was observed in M. cordyla populations between the Arabian Sea and the Bay of Bengal (Sajina et al., 2011) and in brook charr (Imre et al., 2002). These observations could be a consequence of phenotypic plasticity due to hydrological variations including water turbulence and swimming ability.

The coefficients of same sign in PCs are indicative of "size variation" while positive and negative reveal "shape variation" (Sundberg, 1989). However in the present study, both size effect and size variation on morphometric characters was highly predominant. Identical studies showed head and caudal region as the major morphological characters for stock delineation in Rasbora (Muchlisin, 2013) as well as in Channa punctata (Khan et al., 2013). Slight variations among populations of a species prevail due to differences in food preferences and swimming activities, but cannot be reflected as stock heterogeneity (Wimberger, 1992). Contradicting this, studies on C. garua on the basis of univariate analysis found significant variations with varying degree of difference in five populations viz., Yamuna, Betwa, Gomti, Son and Tons rivers (Verma et al., 2014).

Further cross-validation of the morphometrics by DFA exhibited moderate percentage of classification confirming marginal separation in C. garua population. DFA is used to determine the continuous variables that discriminate between two or more naturally occurring groups. The analysis revealed that Allahabad population as the most well-defined group with only $8.48 \%$ of misclassified individuals whereas Farakka showed the highest discriminant value of classification among the three locations. Likewise misclassification report on Heteropneustes fossilis distinctly supported the similarity between its populations (Khan et al., 2012). However, minimal phenotypic differences may be attributed due to water temperature, salinity, food availability and swimming pattern while experiencing specific environmental conditions (Rahman et al., 2014).

The present study of truss network system successfully revealed a single continuous stock of C. garua population in three different locations of the Ganga River. Therefore, a uniform management strategy by developing suitable mesh size/hook size based on this morphometric study for sustainability of $C$. garua could be provided to policy makers. The findings can further be validated by additional studies employing molecular techniques.

\section{Acknowledgements}

The first author wishes to express gratitude to the Vice Chancellor, West Bengal University of Animal and Fishery Sciences, Kolkata for providing necessary infrastructure facility to carry out the work. The support rendered by the Director, ICAR-CIFRI, Barrackpore, West Bengal is well appreciated.

\section{References}

Biswas, I., Nagesh, T. S., Sajina, A. M. and Radhakrishnan, K. 2018. Morphometric variations and meristic counts of Clupisoma garua: An approach for assessing stock structure in the River Ganga. J. Exp. Zool. India, 21(2): 813-822.

Bookstein, F .L., Chernoff, B., Elder, R. L., Humpheries, J. M., Smith, G. R. and Strauss, S. E. 1985. Morphometrics in evolutionary biology, Proc. Acad. Nat. Sci. Philadelphia, 15: 277 pp.

Cadrin, S. X. and Friedland, K. D. 1999. The utility of image processing techniques for morphometric analysis and stock identification. Fish. Res., 43: 129-139.

Cadrin, S. X. and Friedland, K. D. 2005. Morphometric outlines. In: Cadrin, S. X., Friedland, K. D. and Waldman, J. (Eds.), Stock identification methodology. Elsevier Academic Press, Amsterdam, p. 173-184.

CAFF 2006. Conservation assessment of freshwater of central India. National Bureau of Fish Genetic Resources, Lucknow, Uttar Pradesh, India. ISBN: 978-981-902951-9-2.

CAMP 1998. Report of the workshop on Conservation, assessment and management plan for freshwater fishes of India 1997, Zoo Outreach Organisation (ZOO) and National Bureau of Fish Genetic Resources, September 1997, Lucknow, Uttar Pradesh, India, 156 pp.

Cavalcanti, M. J., Monteiro, L. R. and Lopes, P. R. D. 1999. Landmark based morphometric analysis in selected species of Serranid fishes (Perciformes: Teleostei). Zool. Stud., 38(3): $287-294$.

Chondar, S. L. 1999. Biology of finfish and shellfish. SCSC Publishers, India, 514 pp.

Dubey, V. K., Sarkar, U. K., Pandey, A. and Lakra, W. S. 2013. Fish communities and trophic metrics as measures of ecological degradation: a case study in the tributaries of the river Ganga basin, India. Rev. Biol. Trop., 61(3): 1351-1363.

Gulland, J. A. 1971. Ecological aspects of fishery research. Adv. Ecol. Res., 7: 115-176.

Hamilton-Buchanan, F. 1822. An account of the fishes found in the river Ganges and its branches. Archibald Constable and Company, Edinburg, 405 pp. 
Hammer, O., Harper, D. A. T. and Ryan, P. D. 2001. PAST: Paleontological Statistics Software Package for Education and Data Analysis. Palaeontologia Electronica, 4(1): 9.

Hatcher, L. 2003. A step by step approach to using SAS for factor analysis and structural equational modeling. SAS Institute Inc., Cary, NC, USA, p. 57-125.

Hilborn, R. and Walters, C. J. 1992. Quantitative fisheries stock assessment - Choice, dynamics and uncertainty. Chapman \& Hall, New York, 570 pp.

Hora, S. L. 1929. An aid to the study of Hamilton-Buchanan's "Gangetic fishes". Mem. Indian Mus., 9: 169-192.

Hora, S. L. 1938. The game fishes of India. IV. The silond catfish Silonia silondia. J. Bombay Nat. Hist. Soc., 40(2): 137-147.

Hurlbut, T. and Clay, D. 1998. Morphometric and meristic differences between shallow and deep water populations of white hake (Urophycis tenuis) in the southern Gulf of Lawrence. Can. J. Fish. Aquat. Sci., 55(10): 2274-2282.

Ihssen, P. E., Booke, H. E., Casselman, J. M., McGlade, J. M., Payne, N. R. and Utter, F. M. 1981. Stock identification: material and methods. Can. J. Fish. Aquat. Sci., 38: $1838-1855$

Imre, I., McLaughlin, R. L. and Noakes, D. L. G. 2002. Phenotypic plasticity in brook charr: changes in the caudal fin induced by water flow. J. Fish. Biol., 61: 11711181.

IUCN 2017. The IUCN Red List of Threatened Species. Version 2017-2 www.iucnredlist.org (Accessed 10 November 2017).

Jafri, A. K., Khawaja, D. K. and Qasim, S. Z. 1964. Studies on the biochemical composition of some freshwater fishes. I Muscle. Fish. Technol., 1(2): 148-157.

Khan, M. A., Miyan, K. and Khan, S. 2013. Morphometric variation of snakehead fish, Channa punctatus, populations from three Indian rivers. J. Appl. Ichthyol., 29(3): 637-642. https://doi.org/10.1111/j.1439-0426.2012.02058.x.

Khan, M. A., Miyan, K., Khan, S., Patel, D. K. and Ansari, N. G. 2012. Studies on the elemental profile of otoliths and truss network analysis for stock discrimination of the threatened stinging catfish Heteropneustes fossilis (Bloch 1794) from the Ganga River and its tributaries. Zool. Stud., 51(7): $1195-1206$

Kumar, G., Swaraj, P. K. and Maria, R. M. 2012. Low genetic variation suggest single stock of kawakawa Euthynnus affinis (Cantor, 1849) along the Indian Coast. Turk. J. Fish. Aquat. Sci.,12: 555-564.

Lakra, W. S., Sarkar, U. K., Gopalakrishnan, A. and Pandian, A. K. 2010. Threatened freshwater fishes of India. National Bureau of Fish Genetic Resources, Lucknow, Uttar Pradesh, India. ISBN: 978-81-905540-5-3.

Mishra, S. S., Acherjee, S. K. and Chakraborty, S. 2009. Development of tools for assessing conservation categories of siluroid fishes of freshwater and brackishwater wetlands of south-west Bengal, India. Environ. Biol. Fish., 84(4): 395-407.
Muchlisin, Z. A. 2013. Morphometric variations of Rasbora group (Pisces: Cyprinidae) in Lake Laut Tawar, Aceh Province, Indonesia, Based on truss character analysis. HAYATI J. Biosci., 20(3):138-143. https://doi.org/10.4308/ hjb.20.3.138.

Patra, M. K., Acharjee, S. K. and Chakraborty, S. K. 2005. Conservation categories of siluroid fishes in north-east Sundarbans, India. Biodivers. Conserv., 14(8): 1863-1876. https://doi.org/10.1007/s10531-004-1041-0.

Rahman, M. M., Sharker, M. R., Sumi, K. R., Alam, M. A. and Hossen, M. S. 2014. Landmark-based morphometric and meristic variations of stinging catfish, Heteropneustes fossilis (Bloch) among three isolated stocks, the Old Brahmaputra River and the Tanguarhaor and a hatchery. Int. J. Fish. Aquat. Stud., 1(3): 163-170.

Rohlf, F. J. 2006a. tps Util, Version 1.38. http://ife.bio.sunysb. edu/morph. State University of New York, Stony Brook, New York, USA.

Rohlf, F. J. 2006b. tpsDig2, Version 2.1. http://life.bio.sunysb. edu/morph. State University of New York, Stony Brook, New York, USA.

Sajina, A. M., Chakraborty, S. K., Jaiswar, A. K., Pazhayamadam, D. G. and Sudheesan, D. 2011. Stock structure analysis of Megalaspis cordyla (Linnaeus, 1758) along the Indian coast based on truss network analysis. Fish. Res., 108 100-105. https://doi.org/10.1016/j.fishres.2010.12.006.

Saraswat, D., Lakra, W. S., Nautiyal, P., Goswami, M., Shyamakant, K. and Malakar, A. 2013. Genetic characterisation of Clupisoma garua (Hamilton,1822) from six Indian populations using mtDNA cytochrome $\mathrm{b}$ gene. Mitochondrial DNA, DOI: 10.3109/19401736.20 13.782014 .

Sarkar, U. K., Pathak, A. K., Sinha, R. K., Sivakumar, K., Pandian, A. K., Pandey, A., Dubey, V. K. and Lakra, W. S. 2012. Freshwater fish biodiversity in the River Ganga (India): changing pattern, threats and conservation perspectives. Rev. Fish. Biol., 22: 251-272.

SAS 2008. SAS/STAT. User's guide, version 9.1. SAS Institute, Cary, North Carolina, USA, 943 pp.

Siddik, M. A. B., Chaklader, M. R., Hanif, M. A., Nahar, A., Ilham, I., Cole, A. and Fotedar, R. 2017. Variation in the life-history traits of a Schilbid catfish, Clupisoma garua (Hamilton, 1822) in the coastal waters of southern Bangladesh. Chin. J. Oceanol. Limnol., 35(5): 1189-1196.

Strauss, R. E. and Bookstein, F. L. 1982. The truss: body from reconstructions in morphometrics. Syst. Zool., 31: 113-135. DOI: $10.1093 /$ sysbio/31.2.113

Sundberg, P. 1989. Shape and size-constrained principal components analysis. Syst. Zool., 38(2): 166-168. DOI: $10.2307 / 2992386$

Talwar, P. K. and Jhingran, A. G. 1991. Inland fishes of India and adjacent countries, Vol. 2. Oxford and IBH Publishing Co. Pvt. Ltd., New Delhi, p. 595-600. 
Turan, C. 1999. A note on the examination of morphometric differentiation among fish populations: the Truss System. Turk. J. Zool., 23: 259-264.

Verma, J., Kashyap, A. and Serajuddin, M. 2014. Phylogeny based on truss analysis in five populations of freshwater catfish: Clupisoma garua. Int. J. Sci. Res., 3(8): 1414-1418.

Wimberger, P. H. 1992. Plasticity of fish body shape, the effects of diet, development, family and age in two species of
Geophagus (Pisces: Cichlidae). Biol. J. Linnean Soc., 45: 197-218. https://doi.org/10.1111/j.1095-8312.1992.tb00640.x.

Winans, G. A. 1987. Using morphometric and meristic characters for identifying stocks of fish. In: Kumpf, H. E., Vaught, R. N., Grimes, C. B., Johnson, A. G. and Nakamura, E. L. (Eds). NOAA Technical Memorandum NMFS-SEFC, 199, Proceedings of the stock identification workshop. Panama City Beach, Florida, USA, p. 135-146. 